\title{
OCT4 IMMUNOHISTOCHEMISTRY AFTER STAGING LAPAROSCOPIC RETROPERITONEAL LYMPHADENECTOMY FOR TESTICULAR TUMOR
}

\author{
Nikola Knežević ${ }^{1}$,Tomislav Kuliš́1, Luka Penezić ${ }^{1}$, Marijana Ćorić ${ }^{2}$, \\ Ivan Krhen ${ }^{1}$ and Željko Kaštelan ${ }^{1}$
}

${ }^{1}$ Department of Urology, Zagreb University Hospital Centre and School of Medicine, University of Zagreb, Zagreb, Croatia; ${ }^{2}$ Department of Pathology and Cytology, Zagreb University Hospital Centre and School of Medicine, University of Zagreb, Zagreb, Croatia

SUMMARY - Twenty to thirty percent of patients with clinical stage I testicular tumor have metastases in the retroperitoneum. The aim of this study was to evaluate the role of OCT4 immunohistochemistry in histopathologic diagnosis of lymph node metastases in patients with nonseminomatous germ cell testicular tumors. All clinical stage I patients with staging laparoscopic retroperitoneal lymphadenectomy from 2001 until 2009 were included. Archived materials of dissected lymph nodes were reassessed and additional immunohistochemical staining with OCT4 antibody was performed in patients diagnosed as free from metastases. Each slide was visually estimated for the percentage of tumor cells showing nuclear immunoreactivity for OCT4. The study included 93 patients, of which $30(32.3 \%)$ had initially positive retroperitoneal lymph nodes. Of the remaining 63 patients, materials were missing for 5 patients, so additional immunohistochemical staining was performed in $58 \mathrm{pa}^{-}$ tients. Of these, two (3.4\%) patients were OCT4 positive, suggesting a conclusion that they were initially misdiagnosed as stage I and metastasis free. OCT4 proved its value in detecting retroperitoneal metastases. Staging laparoscopic retroperitoneal lymphadenectomy for nonseminomatous germ cell testicular tumors in clinical stage I is a reasonable option for selected patients.

Key words: Laparoscopy; Lymphatic metastasis; Lymph node excision; Staining and labeling; Testicular neoplasms

\section{Introduction}

The incidence of testicular cancer in Croatia has been increasing in the last two decades and, alongside several northern and western Europe countries, is one of the highest in Europe and the world. Although relatively rare, it is the most common solid tumor in young males ${ }^{1}$. The introduction of platinum-based multidrug chemotherapy, careful staging at the time of diagnosis, and prompt and appropriate treatment

Correspondence to: Tomislav Kuliš, $M D, P b D$, Department of Urology, Zagreb University Hospital Centre, Kišpatićeva 12, HR-10000 Zagreb, Croatia

E-mail: tkulis@gmail.com

Received March 14, 2018, accepted July 2, 2018 based on interdisciplinary management have resulted in survival rates of over $95 \%{ }^{2,3}$. More than $95 \%$ of all testicular tumors are germ cell tumors ${ }^{4}$, and are divided into two large subgroups of seminoma and nonseminoma. Around $30 \%$ of patients with clinical stage I nonseminomatous germ cell tumors (NSGCT) have metastatic disease in the retroperitoneum, which cannot be detected using current imaging studies. Staging laparoscopic retroperitoneal lymph node dissection (L-RPLND) is an operative procedure which is performed for NSGCT clinical stage $\mathrm{I}^{5,6}$. Classic histopathologic hematoxylin and eosin stained sections are a standard technique for detecting malignant lesions, but in rare circumstances, a reliable and sensitive immunohistochemical marker would be useful. OCT4 is 
a nuclear transcription factor expressed in early embryonic and germ cells. It has been utilized successfully in detecting neoplastic pluripotent germ cells, specifically seminoma, embryonal carcinoma and intratubular germ cell neoplasia, unclassified (IGCNU) ${ }^{7}$. The aim of this study was to evaluate OCT4 immunohistochemistry in the histopathologic diagnosis of metastases in hematoxylin and eosin negative lymph nodes after staging L-RPLND.

\section{Patients and Methods}

The study was retrospective and included all patients with clinical stage I NSGCT of the testis in whom staging L-RPLND was performed from March 2001 until March 2009. Orchiectomy was the initial treatment in all patients, and serum tumor markers (AFP, $\beta \mathrm{HCG}$ and $\mathrm{LDH}$ ) were analyzed before and after orchiectomy according to their half-life kinetics. Post-orchiectomy radiologic imaging (chest and abdominal computed tomography (CT)) was performed. In case of no clinical signs of metastatic disease, normalization of serum tumor markers, and no metastases or enlarged lymph nodes on CT scan, L-RPLND was performed 1 to 3 months after orchiectomy. Laparoscopic technique used is a modified template RPLND with en bloc resection of lymphatic tissue. The approach is lateral transabdominal with the ipsilateral side elevated by $45-60^{\circ}$ from the operating table. The margins of the dissection were according to the modified template, as we have previously described ${ }^{8}$. Upon approval by the Zagreb University Hospital Centre Ethics Committee, we reassessed the archived materials of dissected lymph nodes and additional OCT4 immunohistochemical staining was done in patients with negative hematoxylin and eosin lymph nodes. The OCT4 staining and material evaluation were performed according to the previously published method ${ }^{7}$. The study was conducted following the principles of the Declaration of Helsinki.

\section{Results}

Ninety-three patients were included in the study. Their mean age at the time of the procedure was 28.8 (range 17-50) years. There were 42 left sided and 51 right sided L-RPLNDs. The mean operating time was

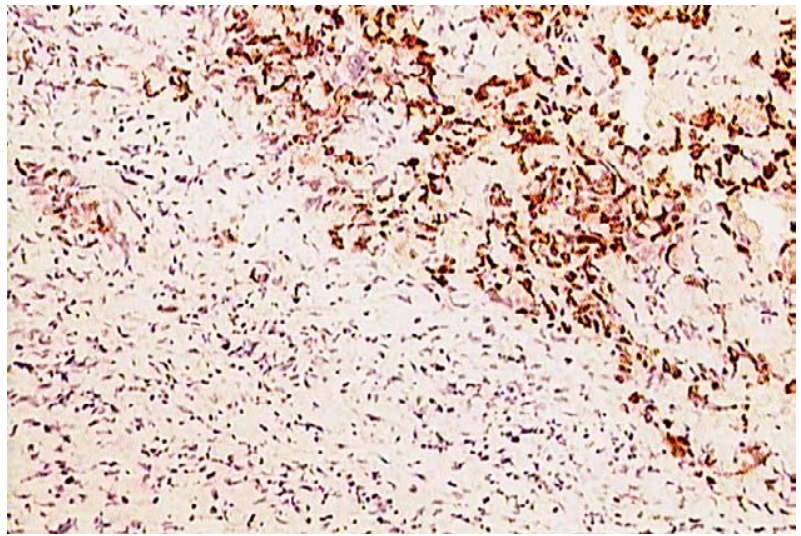

Fig. 1. OCT4 positive nuclear immunoreaction recognizes germ cells in lymph node (OCT4 stain, original magnification X200).

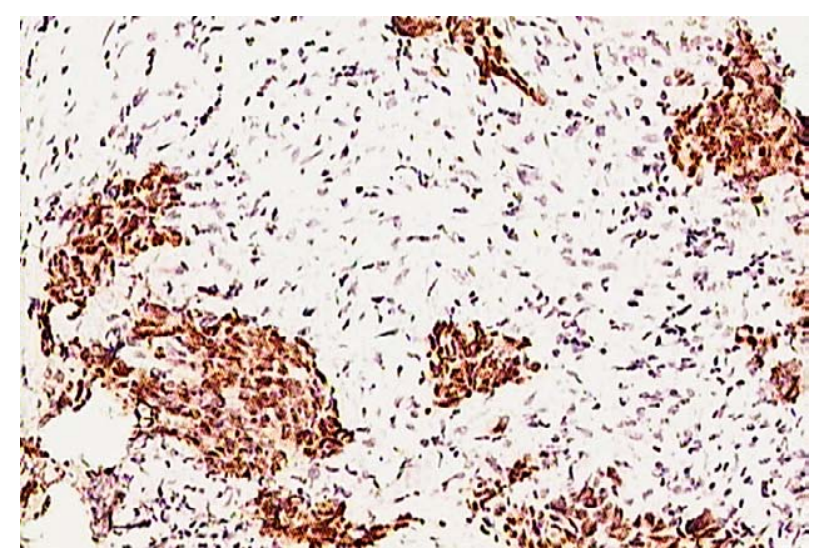

Fig. 2. Neoplastic cells show strong nuclear staining reaction (OCT4 stain, original magnification X100).

180 (range 120-240) minutes. The mean number of lymph nodes obtained for histopathologic examination was 14.2 (range 6-34). Median hospitalization time was 4 (range 3-10) days. There were no major (Clavien Dindo grade II or higher) intraoperative or postoperative complications during the 90-day follow up. One patient had prolonged lymphorrhea and none experienced retrograde ejaculation. Of 93 patients included in the study, 30 (32.3\%) had positive lymph nodes detected by classical histopathologic hematoxylin and eosin stain after staging L-RPLND initially. Of the remaining patients that had negative lymph nodes, materials were missing for five subjects, so they were excluded from the study. Finally, lymph nodes from 58 patients were additionally analyzed immunohistochemically. Among the patients analyzed, we found two (3.4\%) patients that showed OCT4 positiv- 
ity, both in a single lymph node (Figs. 1 and 2). They were initially misdiagnosed as metastasis free. They were from the beginning of our series, to be precise, the $3^{\text {rd }}$ and $7^{\text {th }}$ patients. Both were contacted and interviewed. One was disease free after orchiectomy and LRPLND. The other had biochemical relapse 2 years after orchiectomy and L-RPLND, $\beta$ HCG was elevated, chest and abdominal CT were without enlarged lymph nodes. He was additionally treated with 3 cycles of BEP protocol and has been disease free thereafter.

\section{Discussion}

With this research, we aimed to investigate the value of OCT4 in detecting lymph node metastases after staging L-RPLND. During the period from March 2001 until March 2009, staging L-RPLND was performed in every patient with clinical stage I NSGCT according to current recommendations ${ }^{8}$. This resulted in a substantial number of staging laparoscopic procedures performed in our department, i.e. $93 \mathrm{pa}^{-}$ tients in 8 years. However, there has been a shift in practice regarding indication for this procedure over the last decade ${ }^{9}$, and staging retroperitoneal lymphadenectomy is not the first choice for the same indication anymore. Current guidelines advise surveillance or adjuvant chemotherapy, which narrows the indication for L-RPLND to a group of high-risk patients that are not willing to undergo adjuvant chemotherapy ${ }^{10}$. Our results of $32.3 \%$ initially positive lymph nodes detected using L-RPLND are similar to global trend of retroperitoneal metastases in NSGCT stage I, which is around $30 \% \%^{5,10}$. OCT4 is a POU-domain, octamerbinding transcription factor, also known as POU5F1 and OCT $3^{11,12}$. It is a factor that enables cells to retain their totipotent ability ${ }^{13,14}$, which means it can be found in all stages of oocyte, from unfertilized oocyte to blastocyst and embryonic stem cells ${ }^{15,16}$. It has also been found in pluripotent neoplastic germ cells which include seminoma, dysgerminoma, embryonal carcino$\mathrm{ma}$ and gonadoblastoma ${ }^{11,17,18}$. The nuclei of these neoplastic cells can be marked with an OCT4 antibody ${ }^{19}$. This is useful not only in basic research but also in clinical practice. It has been used to help detect IGC$\mathrm{NU}$ in testicular biopsies ${ }^{12}$ and it has proven its usefulness in detecting testicular germ cell tumors in patients with cryptorchidism ${ }^{7}$. Our research proved its value in detecting retroperitoneal NSGCT metastases. How- ever, the two initially misdiagnosed cases were from the beginning of our series, to be exact, they were the $3^{\text {rd }}$ and $7^{\text {th }}$ patients in this series. The remaining cases were correctly diagnosed and no discrepancy between the original stain and OCT4 immunohistochemistry was found later. Although the guidelines are clear on the topic of staging L-RPLND, discussion and controversies on this procedure are still ongoing ${ }^{20}$. One of the main arguments against staging L-RPLND is that around $70 \%$ of patients with clinical stage I disease will be overtreated. However, since L-RPLND has low morbidity and mortality, it should not be discarded so easily. Some authors propose a risk-adapted indication for L-RPLND ${ }^{21}$.We share a similar opinion. In our hospital, the main reasons to consider staging LRPLND today are as follows: 1) more than $70 \%$ of teratoma elements in orchiectomy histology; 2) patient's personal preference; and 3) initially negative tumor markers. These are like those proposed by Rassweiler et al. ${ }^{5}$ Since the presence of teratoma in primary orchiectomy histology relates to an increased incidence of teratoma in the retroperitoneal lymph nodes after chemotherapy ${ }^{22-24}$, these patients could benefit from staging L-RPLND. We know that around $30 \%$ of patients with clinical stage I disease are actually clinical stage II because of micro metastases in the retroperitoneum. Most of them will be treated successfully with chemotherapy, but there is always a portion that will relapse. It is important to find predictive factors for those relapses. Teratoma is chemotherapy-resistant and its presence was identified as a predictor of late relapses $^{25}$. That is why patients with a higher percentage of teratomatous elements in primary specimen might profit from staging L-RPLND. Logothetis et al. report that $36 \%$ of patients with NSGCT stage II and teratoma in primary specimen are more likely to relapse after initial chemotherapy and would need post chemotherapy RPLND versus $8 \%$ of those who do not $^{26}$. Staging L-RPLND in hands of a skilled surgeon causes less morbidity than post chemotherapy LRPLND, since the complication rate for staging is lower as compared to post chemotherapy L-RPLND ${ }^{27}$. The rationale for staging L-RPLND in clinical stage I NSGCT with a high percentage of teratoma in primary specimen is based on scarce research with small series of patients and there are no randomized controlled trials. Further research on this issue is needed. In the interpretation of our findings, we emphasize the 
importance of pathologist's experience to reduce falsenegative diagnoses. Since the research shows that high volume providers have better surgical outcomes for high-risk surgeries such as $\mathrm{L}^{-R P L N D}{ }^{28}$, the same could be transposed to pathologists as well. Having that in mind, the cost-benefit of OCT4 immunohistochemistry for high volume centers might not be reasonable; however, it could be valuable for low volume centers and novice series at the beginning of the learning curve.

\section{References}

1. Sincic N, Kulis T, Znaor A, Bray F. Time trends in testicular cancer in Croatia 1983-2007: rapid increases in incidence, no declines in mortality. Cancer Epidemiol. 2012;36:11-5, DOI: 10.1016/j.canep.2011.09.010

2. de Wit R, Fizazi K. Controversies in the management of clinical stage I testis cancer. J Clin Oncol. 2006;24:5482-92, DOI:10.1200/JCO.2006.07.9434

3. Tandstad T, Dahl O, Cohn-Cedermark G, Cavallin-Stahl E, Stierner U, Solberg A, et al. Risk-adapted treatment in clinical stage I nonseminomatous germ cell testicular cancer: the SWENOTECA management program. J Clin Oncol. 2009; 27:2122-8, DOI: 10.1200/JCO.2008.18.8953

4. Stephenson AJ, Gilligan TD. Neoplasms of the testis. In: Wein AJ, Kavoussi LR, Campbell MF, et al., editors. CampbellWalsh Urology, $10^{\text {th }}$ edn. Philadelphia, PA: Elsevier Saunders; 2012. p. 837-70.

5. Rassweiler JJ, Scheitlin W, Heidenreich A, Laguna MP, Janetschek G. Laparoscopic retroperitoneal lymph node dissection: does it still have a role in the management of clinical stage I nonseminomatous testis cancer? A European perspective. Eur Urol. 2008;54:1004-15, DOI: 10.1016/j.eururo.2008.08.022

6. Stephenson AJ, Aprikian AG, Gilligan TD, Oldenburg J, Powles T, Toner GC, et al. Management of low-stage nonseminomatous germ cell tumors of testis: SIU/ICUD Consensus Meeting on Germ Cell Tumors (GCT), Shanghai 2009. Urology. 2011;78 Suppl 4:S444-55,

DOI: 10.1016/j.urology.2011.02.030

7. Krhen I, Kulis T, Coric M, Knezevic N, Marekovic Z, Kastelan Z. OCT 4 immunohistochemistry in postpubertal cryptorchidism. Cent Eur J Med. 2010;6:243-6,

DOI: $10.2478 / \mathrm{s} 11536-010-0074-\mathrm{x}$

8. Hudolin T, Kastelan Z, Knezevic N, Goluza E, Tomas D, Coric M. Correlation between retroperitoneal lymph node size and presence of metastases in nonseminomatous germ cell tumors. Int J Surg Pathol. 2012;20:15-8, DOI: 10.1177/10668969 11431452

9. Albrecht W. Defending the EAU 2010 Guidelines on Testis Cancer: Nerve-sparing Retroperitoneal Lymphadenectomy Is Not a Primary Treatment Option for Stage I Nonseminoma.
Eur Urol Suppl. 2011;10 (3):e71-4, DOI: 10.1016/j.eursup.2011.03.009

10. Albers P, Albrecht W, Algaba F, Bokemeyer C, Cohn-Cedermark G, Fizazi K, et al. Guidelines on Testicular Cancer: 2015 Update. Eur Urol. 2015;68:1054-68, DOI: 10.1016/j.eururo.2015.07.044

11. Hansis C, Grifo JA, Krey LC. Oct-4 expression in inner cell mass and trophectoderm of human blastocysts. Mol Hum Reprod. 2000;6(11):999-1004, DOI: 10.1093/molehr/6.11.999

12. Jones TD, Ulbright TM, Eble JN, Cheng L. OCT4: a sensitive and specific biomarker for intratubular germ cell neoplasia of the testis. Clin Cancer Res. 2004;10:8544-7, DOI: 10.1158/1078-0432.CCR-04-0688

13. Palmieri SL, Peter W, Hess H, Scholer HR. Oct-4 transcription factor is differentially expressed in the mouse embryo during establishment of the first two extraembryonic cell lineages involved in implantation. Dev Biol. 1994;166:259-67, DOI: 10.1006/dbio.1994.1312

14. Nichols J, Zevnik B, Anastassiadis K, Niwa H, Klewe-Nebenius D, Chambers I, et al. Formation of pluripotent stem cells in the mammalian embryo depends on the POU transcription factor Oct4. Cell. 1998;95:379-91, DOI: 10.1016/S00928674(00)81769-9

15. Abdel-Rahman B, Fiddler M, Rappolee D, Pergament E. Expression of transcription regulating genes in human preimplantation embryos. Hum Reprod. 1995; 10:2787-92, DOI: 10.1093/oxfordjournals.humrep.a135792

16. Reubinoff BE, Pera MF, Fong CY, Trounson A, Bongso A. Embryonic stem cell lines from human blastocysts: somatic differentiation in vitro. Nat Biotechnol. 2000;18:399-404, DOI: $10.1038 / 74447$

17. Okamoto K, Okazawa H, Okuda A, Sakai M, Muramatsu M, Hamada H. A novel octamer binding transcription factor is differentially expressed in mouse embryonic cells. Cell. 1990; 60:461-72, DOI: 10.1016/0092-8674(90)90597-8

18. Rosner MH, Vigano MA, Ozato K, Timmons PM, Poirier F, Rigby PW, et al. A POU-domain transcription factor in early stem cells and germ cells of the mammalian embryo. Nature. 1990;345:686-92, DOI: 10.1038/345686a0

19. Looijenga LH, Stoop H, de Leeuw HP, de Gouveia Brazao CA, Gillis AJ, van Roozendaal KE, et al. POU5F1 (OCT3/4) identifies cells with pluripotent potential in human germ cell tumors. Cancer Res. 2003;63:2244-50.

20. Heidenreich A, Pfister D. Management of patients with clinical stage I nonseminomatous testicular germ cell tumours: active surveillance versus primary chemotherapy versus nerve sparing retroperitoneal lymphadenectomy. Arch Esp Urol. 2012;65:215-26.

21. Heidenreich A, Albers P, Hartmann M, Kliesch S, Kohrmann KU, Krege S, et al. German Testicular Cancer Study Group. Complications of primary nerve sparing retroperitoneal lymph node dissection for clinical stage I nonseminomatous germ cell tumors of the testis: experience of the German Testicular Can- 
cer Study Group. J Urol. 2003;169:1710-4, DOI: 10.1097/01. ju.0000060960.18092.54

22. Rabbani F, Gleave ME, Coppin CM, Murray N, Sullivan LD. Teratoma in primary testis tumor reduces complete response rates in the retroperitoneum after primary chemotherapy. The case for primary retroperitoneal lymph node dissection of stage IIb germ cell tumors with teratomatous elements. Cancer. 1996;78:480-6, DOI: 10.1002/(SICI)1097-0142(19960801) 78:3<480::AID-CNCR15>3.0.CO;2-V

23. Sagalowsky AI, Ewalt DH, Molberg K, Peters PC. Predictors of residual mass histology after chemotherapy for advanced testis cancer. Urology. 1990;35:537-42, DOI: 10.1016/00904295(90)80112-Z

24. Donohue JP, Rowland RG, Kopecky K, Steidle CP, Geier G, Ney KG, et al. Correlation of computerized tomographic changes and histological findings in 80 patients having radical retroperitoneal lymph node dissection after chemotherapy for testis cancer. J Urol. 1987;137:1176-9.
25. Shahidi M, Norman AR, Dearnaley DP, Nicholls J, Horwich A, Huddart RA. Late recurrence in 1263 men with testicular germ cell tumors. Multivariate analysis of risk factors and implications for management. Cancer. 2002;95:520-30, DOI: 10.1002/cncr.10691

26. Logothetis CJ, Swanson DA, Dexeus F, Chong C, Ogden S, Ayala AG, et al. Primary chemotherapy for clinical stage II nonseminomatous germ cell tumors of the testis: a follow-up of 50 patients. J Clin Oncol. 1987;5:906-11, DOI: 10.1200/ JCO.1987.5.6.906

27. Heidenreich A, Pfister D. Retroperitoneal lymphadenectomy and resection for testicular cancer: an update on best practice. Ther Adv Urol. 2012;4:187-205, DOI: $10.1177 / 1756287212443170$

28. Joudi FN, Konety BR. The impact of provider volume on outcomes from urological cancer therapy. J Urol. 2005;174:432-8, DOI: $10.1097 / 01 . j u .0000165340 .53381 .48$

\section{OCT4 IMUNOHISTOKEMIJA NAKON LAPAROSKOPSKE LIMFADENEKTOMIJE KOD BOLESNIKA S TUMOROM TESTISA}

\section{N. Knežević, T. Kuliš, L. Penezić, M. Ćorić, I. Krhen i Ž. Kaštelan}

Dvadeset do trideset posto bolesnika s tumorom testisa kliničkog stadija I. ima metastaze u retroperitoneumu. Cilj ovoga istraživanja bio je utvrditi vrijednosti OCT4 u patohistološkoj dijagnostici metastaza u limfnim čvorovima dobivenih laparoskopskom retroperitonealnom limfadenektomijom za utvrđivanje proširenosti bolesti. $U$ istraživanje su uključeni bolesnici kliničkog stadija I. koji su operirani u razdoblju od 2001. do 2009. godine. Učinjena je ponovna procjena arhiviranih patohistoloških materijala pričem su uzorci bolesnika za koje je prvobitno utvrđeno da nemaju metastaza dodatno imunohistokemijski obrađeni protutijelima OCT4. Za svako stakalce vizualno je procijenjen postotak tumorskih stanica jezgre kojih su pokazale imunoreakciju za OCT4. Istraživanjem su uključena 93 bolesnika od kojih je $30(32,3 \%)$ inicijalno imalo metastaze u retroperitonealnim limfnim čvorovima. Od preostala 63 bolesnika pet ih nije imalo dostupne materijale za analizu te je imunohistokemijsko bojenje učinjeno za 58 bolesnika. Među njima dijagnosticirali smo dva $(3,4 \%)$ bolesnika koji su imali limfne čvorove pozitivne na OCT4. Njima je inicijalno utvrđen krivi stadij bolesti, čime smo zaključili kako je OCT4 potvrdio svoju vrijednost $\mathrm{u}$ otkrivanju retroperitonealnih metastaza. Laparoskopska retroperitonealna limfadenektomija u svrhu utvrđivanja stadija bolesti predstavlja razumnu opciju za probrane bolesnike u kliničkom stadiju I. neseminomskih tumora zametnih stanica testisa. tumori

Ključne riječi: Laparoskopija; Limfatične metastaze; Limfni ǐvor, odstranjivanje; Bojenje i označavanje preparata; Testis, 